\title{
Nutrient status and field performance of tree seedlings planted in Mediterranean degraded areas
}

\author{
Alejandro VALDECANTOS ${ }^{\mathrm{a}, \mathrm{b} *}$, Jordi CORTINA ${ }^{\mathrm{c}}, \mathrm{V}^{\mathrm{V}}$. Ramón VALLEJO ${ }^{\mathrm{a}}$ \\ a Centro de Estudios Ambientales del Mediterráneo (CEAM), Charles R. Darwin 14, Parque Tecnológico Paterna, 46980 Valencia, Spain \\ b Departament Ecosistemas Agroforestales, EPS Gandía, Universidad Politécnica de Valencia, Ctra Nazaret-Oliva s/n, 46730 Gandía, Valencia, Spain \\ c Departament d'Ecologia, Universitat d'Alacant, Ap 99, 03080 Alacant, Spain
}

(Received 27 January 2005; accepted 3 October 2005)

\begin{abstract}
In degraded Mediterranean woodlands, nutrients, in addition to water, may be the major factors controlling reforestation success. But information on nutritional status of planted seedlings is scarce. We aimed to evaluate the nutritional status and field performance of Pinus halepensis and Quercus ilex seedlings planted on two characteristic Mediterranean forest soils developed from marl and limestone. We used root growth response to localized $\mathrm{N}$ and $\mathrm{P}$ enrichment, and foliar analysis as indicators of nutrient limitation. Vermiculite cores enriched with $\mathrm{P}$ showed higher root density than N-enriched and control cores, particularly on soils derived from marl. Three years after planting, seedlings showed low foliar P and $\mathrm{K}$ as compared to other species and adult trees. Principal Component Analysis conducted on foliar macronutrient concentration clearly separated species and soil type. Foliar $\mathrm{K}$ and $\mathrm{Mg}$ depended on soil type (higher on limestone and marl, respectively), whereas N, P and Ca concentration in leaves and needles differed between species (higher $\mathrm{N}$ and $\mathrm{P}$ in pine, higher Ca in oak). Survival and growth depended on species and site, but we found no effect of soil type on these variables, suggesting that seedling performance may not be strongly affected by nutrient status within the range of soils evaluated.
\end{abstract}

foliar nutrient concentration / nutrient limitation / Pinus halepensis / Quercus ilex / reforestation

Résumé - État nutritionnel et comportement de jeunes arbres plantés dans des terrains méditerranéens dégradés. Le succès des reboisements dans les forêts méditerranéennes dégradées peut être conditionné par la disponibilité en eau et en nutriments. Cependant, il existe peu d'information sur l'état nutritionnel des semis en reboisement. Nous avons évalué l'état nutritionnel et le développement en conditions de terrain des semis de Pinus halepensis et de Quercus ilex plantés dans deux types de sols caractéristiques des forêts méditerranéennes : les marnes et les calcaires. La réponse de la croissance des racines en des points enrichis en $\mathrm{N}$ et $\mathrm{P}$ et les analyses foliaires furent utilisées comme indicateurs de limitation nutritionnelle. Les carottes de vermiculite enrichies en $\mathrm{P}$ montrèrent une plus forte densité de racines que celles enrichies en $\mathrm{N}$ et celles des témoins, spécialement sur les marnes. Trois ans après la plantation, les semis présentèrent une faible teneur en $\mathrm{P}$ et $\mathrm{K}$ foliaire en comparaison avec d'autres espèces et arbres adultes. L'analyse en composantes principales de la concentration foliaire de macro nutriments, sépara clairement les espèces et le type de sol. La concentration foliaire de $\mathrm{K}$ et $\mathrm{Mg}$ dépendait du type de sol (respectivement plus grande sur le calcaire et la marne) alors que la concentration en $\mathrm{N}, \mathrm{P}$ et $\mathrm{Ca}$ fut différente entre les espèces (plus importante en $\mathrm{N}$ et $\mathrm{P}$ chez les pins, et en $\mathrm{Ca}$ chez les chênes). La survie et la croissance dépendaient de l'espèce et du site de plantation, mais on n'a pas rencontré d'effet du type de sol sur ces variables, ce qui suggère que le développement des semis ne peut pas être fortement déterminé par l'état nutritionnel des sols dans la gamme de ceux que nous avons évalués.

concentration foliaire des nutriments / limitation nutritionnelle / Pinus halepensis / Quercus ilex / reboisement

\section{INTRODUCTION}

Mediterranean soils are frequently poor in organic matter due to constraints in plant productivity [9], and long-term land use [29]. In addition, in the driest areas, soils are commonly alkaline, with low levels of available phosphorus [22]. Under Mediterranean conditions, productivity can be related to nutrient availability, and plants frequently respond to fertilization with phosphorus [22, 28, 40] and nitrogen [23, 36, 38].
Plant nutritional status has been frequently related to soil fertility and nutrient availability [5, 11,43], but these relationships are not straightforward, and may depend on life form, species, and on the nutrients involved [1,3]. For example, early successional species may be more responsive to nutrient additions than late successional species $[4,12,21]$, and this may confer competitive advantages to pioneer species in early stages of succession [49]. However, this model may not be valid in ecosystems where long-term disturbances caused nutrient depletion.

\footnotetext{
* Corresponding author: a.valdecantos@ua.es
} 
Table I. Chemical properties and textural class of the $0-10 \mathrm{~cm}$ depth soils developed from marl and limestone in 8 degraded woodland sites in the Region of Valencia (E Spain). Mean and standard error (in brackets) of 4 samples is shown.

\begin{tabular}{|c|c|c|c|c|c|c|c|c|}
\hline Bedrock type & Site & $\mathrm{pH}$ & $\begin{array}{c}\mathrm{CaCO}_{3} \\
(\%)\end{array}$ & $\begin{array}{l}\text { O.M. } \\
(\%)\end{array}$ & $\begin{array}{c}\text { Total N } \\
(\%)\end{array}$ & $\mathrm{C}: \mathrm{N}$ & $\begin{array}{l}\text { Clay } \\
(\%)\end{array}$ & $\begin{array}{c}\text { Textural } \\
\text { Class }^{\mathrm{a}}\end{array}$ \\
\hline \multirow[t]{4}{*}{ Marl } & Ayora & $8.1(0.0)$ & $18(3)$ & $6.3(0.7)$ & $0.26(0.01)$ & $13.8(0.8)$ & $12(0)$ & 1,2 \\
\hline & Martés & $8.2(0.0)$ & $20(2)$ & $6.7(1.0)$ & $0.26(0.04)$ & $15.2(1.5)$ & $11(0)$ & 2 \\
\hline & Yátova 1 & $8.0(0.0)$ & $54(4)$ & $5.6(0.1)$ & $0.26(0.00)$ & $12.4(0.2)$ & $23(2)$ & 1,3 \\
\hline & Yátova 2 & $8.1(0.0)$ & $64(3)$ & $5.5(0.1)$ & $0.22(0.01)$ & $14.3(0.4)$ & $20(1)$ & 1 \\
\hline \multirow[t]{4}{*}{ Limestone } & Buñol & $8.1(0.0)$ & $4(1)$ & $8.5(0.7)$ & $0.46(0.02)$ & $10.8(0.6)$ & $43(1)$ & 4 \\
\hline & Martés & $8.1(0.0)$ & $2(0)$ & $5.7(0.3)$ & $0.33(0.01)$ & $10.0(0.1)$ & $52(1)$ & $5,6,4$ \\
\hline & Lorcha & $7.9(0.0)$ & $0(0)$ & $6.3(0.7)$ & $0.36(0.03)$ & $10.1(0.7)$ & $33(5)$ & $5,3,7,1$ \\
\hline & Simat & $7.6(0.1)$ & $0(0)$ & $5.0(0.5)$ & $0.19(0.02)$ & $15.7(2.6)$ & $21(1)$ & 8 \\
\hline
\end{tabular}

a 1 = Loamy; 2 = Silty loam; 3 = Sandy loam; 4 = Silty clay; 5 = Clay; 6 = Sandy; 7 = Clay loam, 8 = Sandy Clay Loam.

Table II. Chemical properties of the uppermost $2.5 \mathrm{~cm}$ soil. Mean and standard error (in brackets) of 4 samples is shown.

\begin{tabular}{lccccc}
\hline Bedrock type & Site & $\begin{array}{c}\mathrm{Ca}^{2+} \\
\left(\mathrm{cmol}^{(+)} \mathrm{kg}^{-1}\right)\end{array}$ & $\begin{array}{c}\mathrm{Mg}^{2+} \\
\left(\mathrm{cmol}^{(+)} \mathrm{kg}^{-1}\right)\end{array}$ & $\begin{array}{c}\mathrm{K}^{+} \\
\left(\mathrm{cmol}^{(+)} \mathrm{kg}^{-1}\right)\end{array}$ & $\begin{array}{c}\mathrm{P} \text { available } \\
\left(\mathrm{mg} \mathrm{kg}^{-1}\right)\end{array}$ \\
\hline Marl & Ayora & $12.1(0.4)$ & $3.9(0.3)$ & $0.2(0.0)$ & $33.2(2.7)$ \\
& Martés & $17.0(2.2)$ & $3.9(0.6)$ & $0.4(0.0)$ & $51.2(21.3)$ \\
& Yátova 1 & $11.8(0.7)$ & $1.1(0.2)$ & $0.4(0.0)$ & $18.5(3.3)$ \\
Limestone & Yátova 2 & $17.8(2.2)$ & $0.7(0.2)$ & $0.4(0.0)$ & $36.2(5.2)$ \\
& Buñol & $22.8(0.5)$ & $1.5(0.4)$ & $1.0(0.0)$ & $33.0(5.8)$ \\
& Martés & $20.0(1.1)$ & $1.6(0.2)$ & $0.8(0.0)$ & $20.5(5.2)$ \\
& Lorcha & $24.6(1.2)$ & $2.5(0.4)$ & $0.7(0.1)$ & $33.2(3.2)$ \\
& Simat & $15.8(1.3)$ & $1.2(0.1)$ & $0.4(0.0)$ & $18.5(4.5)$ \\
\hline
\end{tabular}

Water is the major factor affecting seedling establishment under Mediterranean conditions [19]. But low nutrient availability could also delay root growth, and reduce seedling capacity to reach deep soil horizons before the onset of summer drought [10]. In addition, adjustments to low nutrient availability may have a negative impact on seedling ability to capture and transport water [18]. Despite evidence of nutrient limitations in Mediterranean areas, little information is currently available on the nutrient status of seedlings of woody species and on the potential implications for afforestation programmes.

We evaluated foliar nutrient concentration in Pinus halepensis L. (Aleppo pine) and Quercus ilex ssp. ballota (Desf.) Samp. (holm oak) seedlings planted on soils developed from limestone and marl in the Region of Valencia (eastern Spain). Our main objectives were (1) to assess the nutritional status of Pinus halepensis and Quercus ilex seedlings planted in two forest soils characteristics of the Mediterranean Basin, developed from limestone and marl, and (2) to discuss the relationship between nutritional status and field performance based on early survival and growth.

Pinus halepensis and Quercus ilex are among the most widespread tree species in the Mediterranean Basin. They tolerate basic soils, and they show contrasting ecological strategies [32]. Pinus halepensis is a heliophyte and obligate seeder species that can readily establish after wildfire from serotinous cones [42]. Quercus ilex is a sprouting tree that can stand some degree of shading [16]. In terms of water economy, $P$. halepensis can be considered a drought avoider species as compared to
Q. ilex [32]. Soils developed from limestone and marl cover vast areas of the Mediterranean Basin [27]. They represent a range of soil properties, from fissural decarbonated fine-textured terra rossa soils, developed from limestone, to highly carbonated and predominantly silty soils developed from marl. Vegetation type and past land use may be contrasting on both soil types, as rock outcrops in soils derived from limestone precluded agricultural uses in the past.

\section{MATERIALS AND METHODS}

\subsection{Field sites}

We selected eight sites in the province of Valencia (E Spain) that were affected by wildfires during the summer of 1991. In February 1993, we established one $50 \times 50 \mathrm{~m}$ plot in each of the four sites with carbonated soils derived from marl (Cambisol and Regosol; Ayora, Martés, Yátova 1 and Yátova 2 [17]), and one $50 \times 50 \mathrm{~m}$ plot in each of the four sites with decarbonated soils derived from limestone (Leptosol; Buñol, Lorcha, Martés and Simat [17]). In each plot, we planted 150 ten-month-old seedlings of Pinus halepensis, and the same number of Quercus ilex ssp. ballota on $40 \times 40 \times 40 \mathrm{~cm}$ planting holes. Species distribution was at random. In spring 1993, we took sixteen $0-10 \mathrm{~cm}$ depth and $0-2.5 \mathrm{~cm}$ depth soil samples per site (from the planting hole and the unaltered soil, respectively), and grouped them into four composite samples for a given depth. After air-drying and sieving, we analyzed the soil for $\mathrm{pH}$, carbonates, organic matter, total nitrogen, texture $(0-10 \mathrm{~cm}$ depth), exchange cations and available phosphorus (0-2.5 cm depth). Soil properties of surface soils of the experimental sites are described in Tables I and II. Total carbonate content was determined by using Bernard's calcimeter, organic $\mathrm{C}$ by 
using Walkley-Black method, total $\mathrm{N}$ by using a semi-micro Kjeldahl, exchangeable cations by $\mathrm{BaCl}_{2}$-triethanolamine extraction at $\mathrm{pH} 8.2$, and ICP spectrometry [30], and available $\mathrm{P}$ by using Olsen bicarbonate extraction [47]. Climate is Mediterranean dry sub-humid with mean annual rainfall ranging from 384 to $592 \mathrm{~mm}$ (weather stations at Ayora, Embalse de Forata and Benissa). In 1994-1995, rainfall was around $60 \%$ of the historical annual average, whereas in 1993, rainfall was close to historical values in six sites (Ayora, Buñol, Martés M and L, Yátova 1 and 2), and in two sites it rained $33 \%$ more than in the longterm series (Lorcha and Simat). All plots are on South-facing moderate slopes, and showed no evidences of agricultural use within the last $2-$ 3 decades. The terms marl and limestone will be used throughout the text to refer to soils derived from each bedrock type.

\subsection{Nutrient limitation in standing vegetation}

We evaluated nitrogen and phosphorus limitation in standing vegetation by using the enriched core technique [14], as described by Raich et al. [34]. We filled $200 \mathrm{~cm}^{3}$ plastic cores with vermiculite. The sides of the cores were opened to expose $50 \%$ of the surface. In November 1997, cores were soaked in deionized water (Control), $0.1 \mathrm{M} \mathrm{NH}_{4} \mathrm{Cl}(\mathrm{N}+$ treatment$)$, or $0.1 \mathrm{M} \mathrm{H}_{3} \mathrm{PO}_{4}(\mathrm{P}+$ treatment $)$, and inserted in the surface soil $(0-10 \mathrm{~cm})$ of two experimental plots representing sites with soils developed from limestone and marl. Ten cores per treatment and site were used. Cores remained in the soil for 6 months. This ensured abundant root colonization, as evidenced by regular observations of an additional set of test cores. In April 1998, cores were recovered, and roots were carefully separated from soil and vermiculite by sonication (Sonifier I Ultrasonic Cell Disruptor Model 250; Branson Ultrasonic SA, USA), washed with distilled water, dried at $60{ }^{\circ} \mathrm{C}$, and weighed.

\subsection{Seedling survival and morphology}

In June 1995, two and a half years after planting, we recorded all surviving seedlings, and measured stem height and root collar diameter on a randomly selected subset of 25 seedlings per site and species.

\subsection{Leaf and needle sampling and analysis}

In July 1997, we collected one-year-old needles and leaves from 10 randomly selected Pinus halepensis and Quercus ilex seedlings per plot. The number of $Q$. ilex seedlings sampled in Yátova 2 (on marl) was 5, and it was not possible to sample Q. ilex seedlings in the Buñol site (on limestone) due to the reduced number of surviving individuals. Seasonal changes in foliar nutrient concentration may affect nutritional diagnosis [6]. Optimum sampling dates may depend on site, species and internal nutrient dynamics [45]. We sampled foliage during the summer because growth rate is low, nutrient concentration relatively stable, and because we expected nutrient limitations to emerge during the period when foliar nutrient concentrations commonly reach a minimum [31, 39]. Leaves and needles were dried at $60^{\circ} \mathrm{C}$, weighed, ground in a stainless steel mill, and digested with concentrated $\mathrm{H}_{2} \mathrm{SO}_{4}$ and $\mathrm{H}_{2} \mathrm{O}_{2}(30 \% \mathrm{v} / \mathrm{v})$. We determined $\mathrm{N}$ concentration by using semimicro Kjeldahl distillation (Tecator Kjeltec Auto 1030 Analyzer, Hogana, Sweden), and $\mathrm{P}, \mathrm{K}, \mathrm{Ca}$ and $\mathrm{Mg}$ concentration by ICP spectrometry (Perkin Elmer Optima 3000, Perkin Elmer Corp., Norwalk, CT, USA). Nutrient content in leaf and needles was determined by multiplying foliar dry weight by nutrient concentration. Vector diagnosis [48] is a graphycal technique to simultaneously evaluate seedling nutrient content and concentration and seedling biomass (leaf and needle dry weight) in order to identify nutrient disorders under different growing conditions. One of the experimental conditions (seedlings planted in limestone, in our study) is normalized to 100 to allow comparisons on a common base.

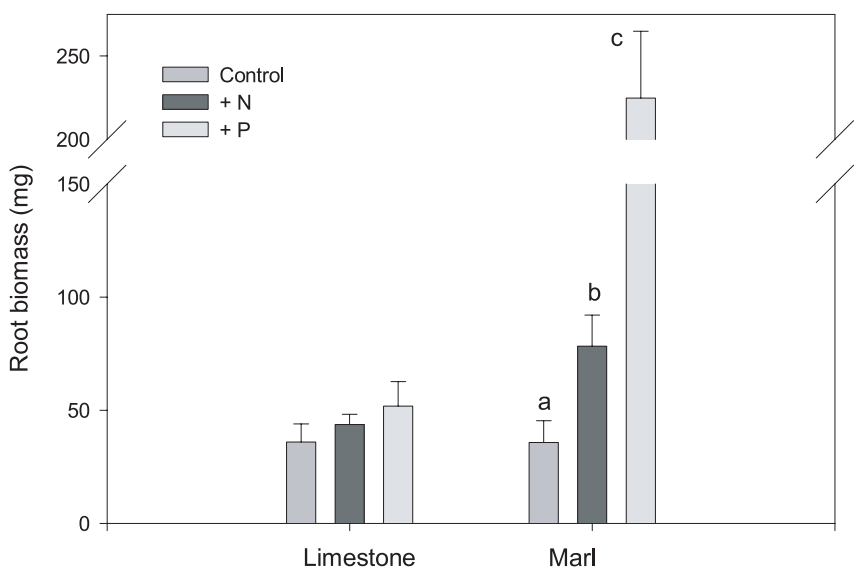

Figure 1. Biomass of fine roots colonizing vermiculite cores watered with deionized water (control), or $\mathrm{N}$ or $\mathrm{P}$ enriched solutions $(+\mathrm{N}$ and $+\mathrm{P}$, respectively). Different letters correspond to significant differences $(P<0.050)$.

\subsection{Data analysis}

We performed a two-way analysis of variance with two fixed factors (soil type and nutrient) to evaluate differences in root growth in the enriched core experiment. Mean separations were assessed by using Tukey's HSD test when suitable. We evaluated the effect of soil type and site on the nutrient status of both species by using ANOVA with one fixed factor (soil type) and one nested random factor (site). Between-species differences were evaluated by first removing the site factor, and thus avoiding the missing cell resulting from the lack of data for Quercus ilex on one limestone site. Nutrient concentrations were log-transformed when needed to avoid heteroscedasticity. We used principal component analysis for exploring the structure of the entire data set on nutrient concentration. Differences in seedling survival were analyzed by log-linear test, and seedling height and root collar diameter by analysis of variance with one fixed (soil type) and one random factor (site). Relationships between seedling morphological variables and plant nutrients were assessed by Pearson correlation analysis. All analysis were carried out by using SPSS v.11.0 statistical package (SPSS Inc., Chicago, IL, USA).

\section{RESULTS}

\subsection{Nutrient limitation in standing vegetation}

Vermiculite cores showed contrasting root biomass accumulation in soils derived from marl and limestone (112.9 and $43.8 \mathrm{mg}$, respectively; $F=13.45, P=0.001$ ) (Fig. 1). Local enrichment in $\mathrm{N}$ and, especially, in $\mathrm{P}$ significantly increased root growth $(F=16.14, P=0.000)$. The significant interaction between soil type and nutrient enrichment $(F=7.47, P=0.001)$ resulted from a contrasting magnitude of the response in both soil types. Local P enrichment resulted in a 144 to $630 \%$ increase in root density in soils derived from limestone and marl, respectively. Vegetation was also sensitive to $\mathrm{N}$ enrichment, but the magnitude of the response was smaller (21 and $119 \%$ increase in soils derived from limestone and marl, respectively), and it was statistically significant only on marl. 

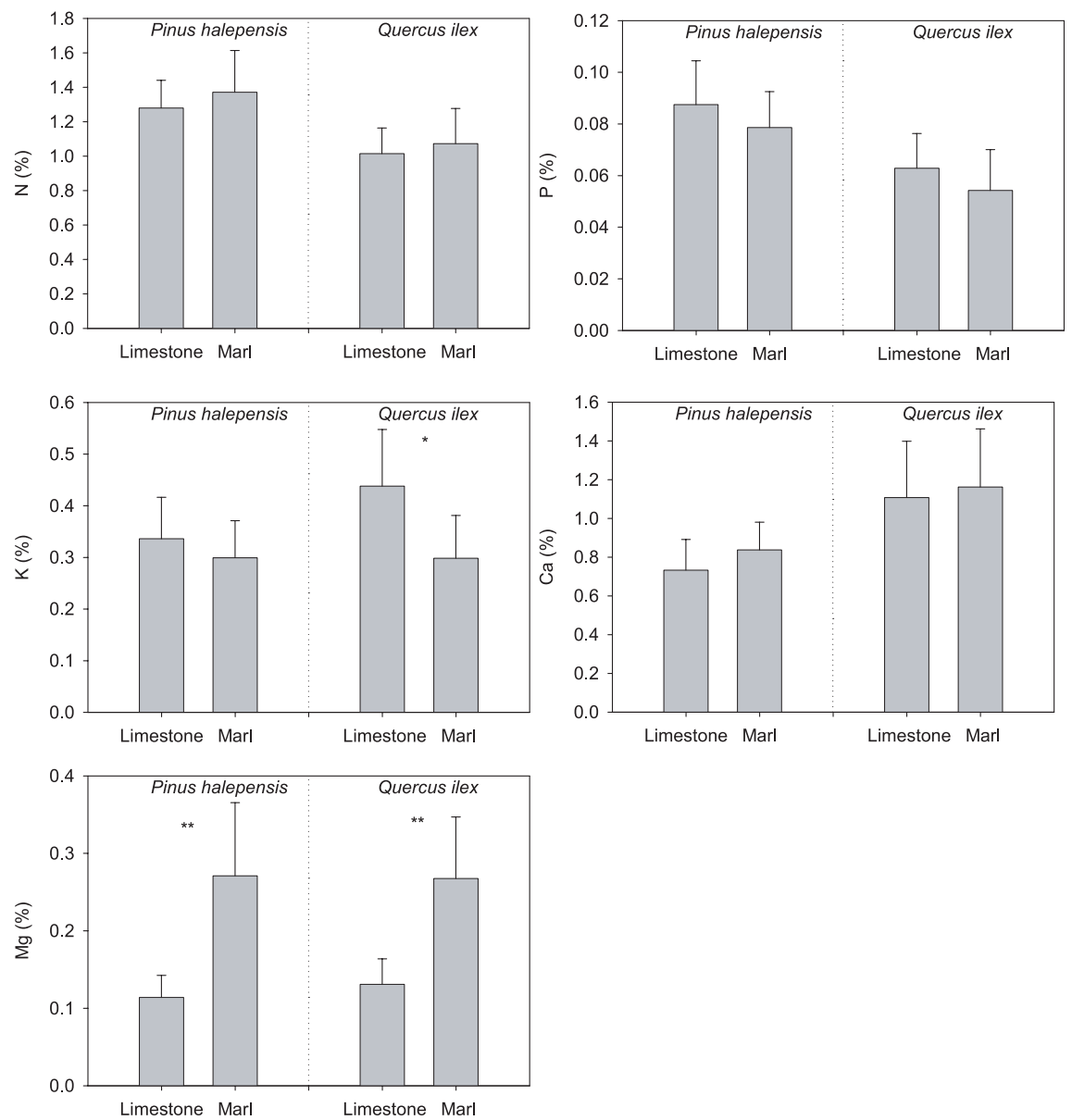

Figure 2. Needle and leaf nutrient concentration in Pinus halepensis and Quercus ilex seedlings growing on soils developed from limestone and marl (mean and standard deviation). ${ }^{*} P<0.050 ; * * P<0.010$.

\subsection{Seedling nutrient status}

We found no significant effect of soil type on foliar N, P and Ca concentration in either of the two species (Fig. 2). Potassium concentration was lower in soils derived from marl, but the difference was only significant for Quercus ilex $(F=8.88, P=$ 0.030). Seedlings growing on marl showed higher foliar $\mathrm{Mg}$ concentration than those growing on limestone $(F=17.80, P=$ 0.006 and $F=21.20, P=0.006$ for $P$. halepensis and $Q$. ilex, respectively). The $\mathrm{N}: \mathrm{Mg}$ ratio in the latter doubled the ratio found in the former (11 vs. 5, and 8 vs. 4 for P. halepensis and $Q$. ilex, respectively).

Correlation coefficients between nutrient concentrations were low but significant in some cases. Magnesium concentration was correlated with that of other nutrients in $P$. halepensis needles (Tab. III). The higher the Mg concentration, the higher the $\mathrm{N}$ and $\mathrm{Ca}$ concentration, and the lower the $\mathrm{P}$ and $\mathrm{K}$ concentration. We also observed a negative relationship between needle $\mathrm{K}$ and $\mathrm{Ca}$ concentration. In $P$. halepensis seedlings planted on marl, correlations between $\mathrm{Mg}$ and $\mathrm{N}$, and $\mathrm{Mg}$ and $\mathrm{Ca}$ were still positive, whereas correlations between $\mathrm{K}$ and $\mathrm{N}$, and $\mathrm{K}$ and $\mathrm{P}$ were negative. On limestone, needle $\mathrm{N}$ concentration was positively related to $\mathrm{P}$ concentration, and $\mathrm{K}$ concentration decreased as $\mathrm{Ca}$ concentration increased. In Q. ilex leaves nutrient concentrations followed similar patterns. In this species foliar $\mathrm{P}$ correlated positively with $\mathrm{Ca}$, and $\mathrm{K}$ correlated negatively with $\mathrm{Ca}$ and $\mathrm{Mg}$. When sorting the data base by soil types, we observed that only the relations between $\mathrm{P}$ and $\mathrm{Ca}$ (positive), and between $\mathrm{K}$ and $\mathrm{Mg}$ (negative) were significant on both marl and limestone (Tab. III).

Species differed in nutrient concentration except for $\mathrm{Mg}$. Pinus halepensis showed higher $\mathrm{N}(F=83.02, P=0.000)$ and $\mathrm{P}(F=94.71, P=0.000)$, and lower $\mathrm{K}(F=10.16, P=0.002)$ and $\mathrm{Ca}(F=82.89, P=0.000)$ than $Q$. ilex. Results of the principal components analysis clearly discriminated species and soil types (Fig. 3). The first component accounted for 34\% of the variance (eigenvalue $=1.685$ ), and the second component for an additional $32 \%$ (eigenvalue $=1.609$ ). Pinus halepensis seedlings distributed mostly on positive values of the first component (PC1), and $Q$. ilex on negative ones. Foliar N (eigenvector score 0.804$), \mathrm{P}(0.762)$ and $\mathrm{Ca}(-0.796)$ were extracted in $\mathrm{PC} 1$. The second component (PC2) separated seedlings planted on marl (positive) and limestone (negative). Foliar $\mathrm{Mg}$ (eigenvector 0.864$)$ and $\mathrm{K}(-0.796)$ were mainly associated with PC2. 
Table III. Pearson correlation coefficients between nutrient concentration in needles of Pinus halepensis, and leaves of Quercus ilex. Significant correlations in bold $(P<0.050) . \mathrm{L}=$ limestone; $\mathrm{M}=$ marl, $\mathrm{All}=$ limestone and marl.

\begin{tabular}{|c|c|c|c|c|c|c|c|c|c|c|c|}
\hline & \multicolumn{5}{|c|}{ Pinus halepensis } & \multicolumn{5}{|c|}{ Quercus ilex } \\
\hline & & $\mathrm{N}$ & $P$ & $\mathrm{~K}$ & $\mathrm{Ca}$ & $\mathrm{Mg}$ & $\mathrm{N}$ & $\mathrm{P}$ & K & $\mathrm{Ca}$ & $\mathrm{Mg}$ \\
\hline \multirow[t]{5}{*}{$\mathrm{L}$} & $\mathrm{N}$ & 1.000 & 0.642 & 0.186 & 0.049 & -0.067 & 1.000 & 0.195 & -0.246 & 0.142 & 0.236 \\
\hline & $\mathrm{P}$ & & 1.000 & 0.296 & 0.286 & -0.081 & & 1.000 & -0.073 & 0.404 & -0.136 \\
\hline & K & & & 1.000 & -0.365 & -0.106 & & & 1.000 & -0.404 & -0.526 \\
\hline & $\mathrm{Ca}$ & & & & 1.000 & 0.253 & & & & 1.000 & 0.116 \\
\hline & $\mathrm{Mg}$ & & & & & 1.000 & & & & & 1.000 \\
\hline \multirow[t]{5}{*}{ M } & $\mathrm{N}$ & 1.000 & -0.070 & -0.350 & 0.177 & 0.500 & 1.000 & 0.132 & 0.253 & -0.158 & 0.276 \\
\hline & $\mathrm{P}$ & & 1.000 & -0.450 & 0.134 & -0.062 & & 1.000 & 0.264 & 0.382 & 0.0165 \\
\hline & K & & & 1.000 & -0.207 & -0.312 & & & 1.000 & -0.093 & -0.427 \\
\hline & $\mathrm{Ca}$ & & & & 1.000 & 0.351 & & & & 1.000 & 0.322 \\
\hline & $\mathrm{Mg}$ & & & & & 1.000 & & & & & 1.000 \\
\hline \multirow[t]{5}{*}{ All } & $\mathrm{N}$ & 1.000 & 0.162 & -0.164 & 0.182 & 0.414 & 1.000 & 0.100 & -0.076 & -0.023 & 0.022 \\
\hline & $\mathrm{P}$ & & 1.000 & 0.049 & 0.108 & -0.244 & & 1.000 & 0.241 & 0.345 & -0.195 \\
\hline & $\mathrm{K}$ & & & 1.000 & -0.349 & -0.322 & & & 1.000 & -0.263 & -0.650 \\
\hline & $\mathrm{Ca}$ & & & & 1.000 & 0.423 & & & & 1.000 & 0.235 \\
\hline & $\mathrm{Mg}$ & & & & & 1.000 & & & & & 1.000 \\
\hline
\end{tabular}

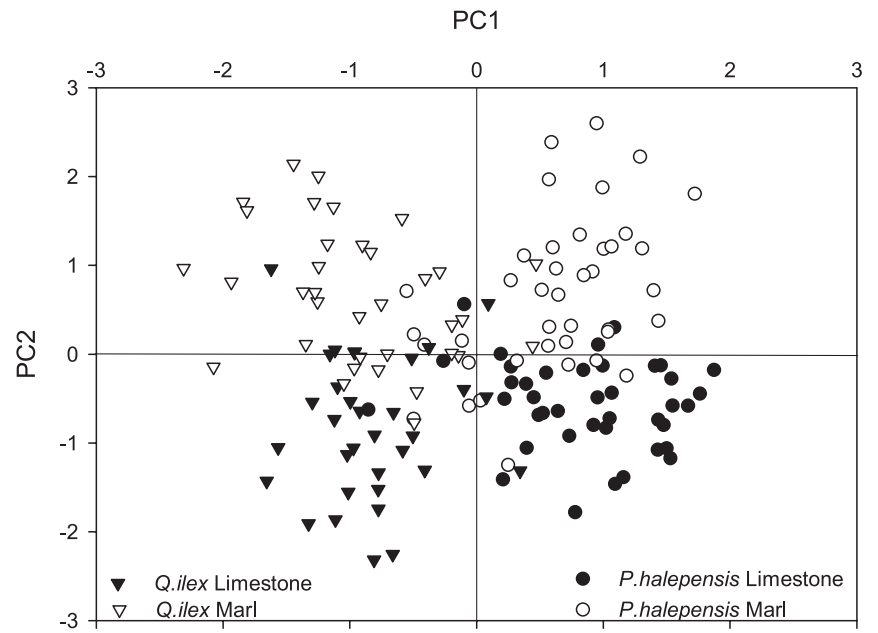

Figure 3. Distribution of Pinus halepensis and Quercus ilex seedlings planted on soils developed from marl and limestone on the two principal components axes derived from foliar nutrient data.

\subsection{Seedling survival and morphology}

Seedling performance in the field was strongly dependent on site (Tab. IV). Survival rate 2.5 years after planting ranged from 32 to $91 \%$ in P. halepensis, and from 4 to $63 \%$ in $Q$. ilex. Differences between species were significant $\left(\chi^{2}=157.5, P=\right.$ 0.000). Soil type had no significant effect on seedling survival, despite a trend towards higher survival rates on marl than on limestone (71 vs. $56 \%$, and 50 vs. $28 \%$ for P. halepensis and Q. ilex, respectively). Similarly, seedlings planted on marl were bigger than on limestone, but differences were not statistically

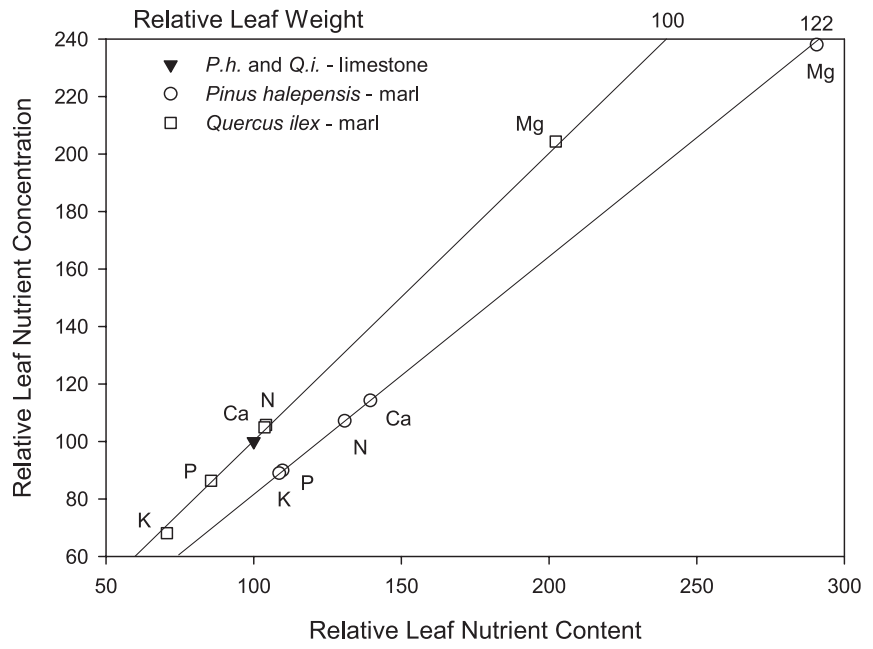

Figure 4. Graphical vector analysis of Pinus halepensis and Quercus ilex seedlings for $\mathrm{N}, \mathrm{P}, \mathrm{K}, \mathrm{Ca}$ and $\mathrm{Mg}$. Data from seedlings planted on limestone (black triangle) were used as reference (100 value for leaf weight, nutrient content and concentration). Diagonal lines indicate foliar dry weight.

significant. Differences in average needle and leaf weight between both soil types were only marginally significant for $P$. halepensis. Thus, the pattern showed by nutrient contents was similar to that found for nutrient concentration. Only $\mathrm{Mg}$ content in leaves and needles of both species was higher on marl than on limestone. The pattern described by vector analysis (Fig. 4), i.e. an increase in $\mathrm{Mg}$ concentration and content with no changes in average needle weight, may be related to luxury consumption. In general terms, seedling size was not related to nutrient status in either of the two species. Only stem height was 
Table IV. Survival, shoot length (SL) and root collar diameter (RCD) of seedlings of Pinus halepensis and Quercus ilex 2.5 years after outplanting in eight degraded woodland sites on soils derived from limestone (L) and marl (M). Seedling size calculated from 25 surviving individuals per site (mean and standard error). No Q. ilex seedling survived in the Buñol site.

\begin{tabular}{|c|c|c|c|c|c|c|c|}
\hline \multirow[b]{2}{*}{ Bedrock type } & \multirow[b]{2}{*}{ Site } & \multicolumn{3}{|c|}{ Pinus halepensis } & \multicolumn{3}{|c|}{ Quercus ilex } \\
\hline & & Survival (\%) & $\mathrm{SL}(\mathrm{cm})$ & $\mathrm{RCD}(\mathrm{cm})$ & Survival (\%) & $\mathrm{SL}(\mathrm{cm})$ & $\mathrm{RCD}(\mathrm{cm})$ \\
\hline \multirow[t]{4}{*}{$\mathrm{L}$} & Buñol & 32 & $17.6(1.1)$ & $0.40(0.02)$ & 4 & - & - \\
\hline & Martés & 59 & $17.1(0.9)$ & $0.34(0.02)$ & 35 & $11.2(0.6)$ & $0.36(0.01)$ \\
\hline & Lorcha & 68 & $23.7(1.7)$ & $0.60(0.05)$ & 38 & $13.5(0.8)$ & $0.41(0.02)$ \\
\hline & Simat & 79 & $14.5(0.7)$ & $0.37(0.02)$ & 36 & $11.9(1.0)$ & $0.36(0.02)$ \\
\hline \multirow[t]{4}{*}{ M } & Ayora & 63 & $26.4(1.7)$ & $0.58(0.06)$ & 57 & $11.9(0.8)$ & $0.37(0.02)$ \\
\hline & Martés & 91 & $16.0(0.8)$ & $0.40(0.02)$ & 63 & $13.8(1.0)$ & $0.41(0.02)$ \\
\hline & Yátova 1 & 65 & $25.7(1.3)$ & $0.51(0.03)$ & 38 & $10.8(1.1)$ & $0.28(0.02)$ \\
\hline & Yátova 2 & 81 & $25.5(2.0)$ & $0.63(0.05)$ & 59 & $12.7(0.8)$ & $0.37(0.02)$ \\
\hline
\end{tabular}

Table V. Pearson correlations coefficients (and $P$ values in brackets) between seedling size and nutrient concentration in needles of Pinus halepensis, and leaves of Quercus ilex.

\begin{tabular}{lccccc}
\hline & \multicolumn{2}{c}{ Pinus halepensis } & & \multicolumn{2}{c}{ Quercus ilex } \\
\cline { 2 - 3 } \cline { 5 - 6 } & $\mathrm{SL}$ & $\mathrm{RCD}$ & & $\mathrm{SL}$ & $\mathrm{RCD}$ \\
\hline $\mathrm{N}$ & 0.085 & 0.181 & & 0.059 & 0.137 \\
& $(0.452)$ & $(0.108)$ & & $(0.630)$ & $(0.259)$ \\
$\mathrm{P}$ & 0.293 & 0.130 & & -0.061 & -0.137 \\
& $(0.008)$ & $(0.252)$ & & $(0.616)$ & $(0.259)$ \\
$\mathrm{K}$ & -0.085 & -0.196 & & 0.132 & -0.146 \\
& $(0.455)$ & $(0.081)$ & & $(0.277)$ & $(0.227)$ \\
$\mathrm{Ca}$ & 0.134 & 0.209 & & -0.070 & 0.038 \\
& $(0.236)$ & $(0.063)$ & & $(0.568)$ & $(0.758)$ \\
$\mathrm{Mg}$ & 0.089 & 0.044 & & 0.047 & 0.173 \\
& $(0.431)$ & $(0.700)$ & & $(0.701)$ & $(0.155)$ \\
\hline
\end{tabular}

significantly correlated with needle $\mathrm{P}$ concentration in $P$. halepensis, but the magnitude of the relationship was rather low (Tab. V).

\section{DISCUSSION}

Foliar nutrient concentrations in this study fell within the range found under similar soil types and climatic conditions $[11,15,20]$. Nitrogen accession by $P$. halepensis seedlings is probably sufficient, according to the nutrient levels suggested for adult trees of this species [6], whereas $\mathrm{P}$ and $\mathrm{K}$ concentration are probably critical, and response to nutrient additions likely. Response of $P$. halepensis seedlings growing on calcareous soils to $\mathrm{P}$ fertilization has been shown under shadehouse conditions [40], despite the fact that in this study seedling response was not proportional to the dose applied. To our knowledge, critical nutrient levels for $Q$. ilex have not been defined. However, as compared to critical levels suggested by Bonneau [8] for other woody species, and $\mathrm{P}$ and $\mathrm{K}$ concentrations reported in other studies $[2,13,35,39], Q$. ilex seedlings were probably limited by both nutrients in these degraded Mediterranean woodlands. According to Koerselman and Meuleman [26], N:P ratios above 16 and below 14 may indicate $\mathrm{P}$ and $\mathrm{N}$ limitation, respectively. Our results suggest that seedlings growing on marl were strongly limited by $\mathrm{P}$, as the $\mathrm{N}: \mathrm{P}$ ratio was 18 and 21 for $P$. halepensis and $Q$. ilex, respectively. Phosphorus limitation has been reported in other studies in Mediterranean areas, particularly on alkaline soils $[22,37,41]$, and in $P$. halepensis and $Q$. ilex seedlings under less stressful climatic conditions [40].

Principal component analysis performed on foliar nutrient concentrations clearly separated plant species and soil types. The first component of the PCA discriminated the two species on the basis of their N, P and Ca foliar concentration. Pinus halepensis seedlings showed higher $\mathrm{N}$ and $\mathrm{P}$ concentration than $Q$. ilex. This fact may be related to the potential relative growth rate of the studied species, being higher in the conifer than in the broadleaved [7, 13]. Quercus ilex is considered a late-successional species with lower growth rates [32], and low nutrient requirements as compared to early-successional $P$. halepensis [21]. Pioneer species tend to keep foliar concentration of the most-limiting nutrient at relatively constant levels when its availability increases, using the extra nutrient inputs for increasing growth. Late-successional species may maintain low growth rates, and may allocate supplemental nutrient inputs to belowground storage organs [33]. Comparative experiments using $P$. halepensis and $Q$. ilex seedlings have shown that foliar nutrient concentration in the latter species is less sensitive to fertilization [44]. Pinus halepensis may respond to nutrient inputs by increasing growth and foliar nutrient concentration [15, 44].

We failed to observe an effect of soil type on foliar $\mathrm{N}$ and $\mathrm{P}$ concentration, whereas the effect was clear in the enriched core experiment. This suggests that the enriched core technique may be more sensitive to nutrient limitations than methods based on foliar nutrient concentrations. Despite the fact that both methods have been used as indicators of nutrient limitation, they may in fact measure different aspects of plant nutrient economy (different strategies). Root growth response may be more sensitive to nutrient availability at low nutrient availability levels [25], 
whereas nutrient concentration may be relatively stable at low to optimum nutrient availability levels, when additional nutrient inputs are assigned to new growth with no major changes in nutrient concentration [24], but may be more sensitive to high nutrient availability levels (e.g. fertilization trials). We should bear in mind, however, that other factors may contribute to the contrasted root growth response to localized nutrient enrichment found in both soil types (e.g. soil physical properties, root density and distribution, community composition, etc.), and that this method should be used with caution for the comparison between contrasted soil types; rather than use it for comparison between nutrients for a given site.

We did not observe any relationship between soil type or seedling nutrient status and field performance. On the contrary, seedlings planted on soils developed from marl appeared to be more stressed, from a nutritional point of view, than those planted on limestone, but seedling survival and growth tended to be higher on the former. Vector analysis showed only marginal differences in average needle weight between soil types. But the pattern for leaf and needle nutrient content was similar to that found for nutrient concentration. Thus, we must then exclude the possibility that the small differences in nutrient concentration between seedlings planted on marl and limestone resulted from parallel changes in nutrient content and leaf or needle weight. The higher $\mathrm{Mg}$ availability on marls did not result in higher growth, suggesting luxury consumption, or storage for subsequent translocation [48]. Other factors, such as those related to water availability, effective soil volume or local biotic and abiotic conditions, may be more relevant for explaining plantation success than differences in soil nutrient availability between the two soil types evaluated in our study. Higher survival rates in woody seedlings planted on soils developed from marls as compared to limestone have been related to higher capacity to store available water [46].

The lack of a clear relationship between nutrient status and seedling performance does not necessarily indicate sufficient nutrient levels or lack of response to fertilization. Despite the relative heterogeneity in soil types, the range of nutrient availability levels present in the study sites may have been too small to show any significant effect on seedling survival and growth. Phosphorus and potassium fertilization on both soil types, and magnesium fertilization on limestone, may improve seedling establishment and further growth under the conditions of the present study, provided that nutrient availability is increased beyond the levels found under natural conditions. It is worth noting, however, that standing vegetation may strongly respond to nutrient inputs, particularly on marls, as observed with the enriched core technique. Thus, competition belowground is likely to be promoted by localized fertilization.

We conclude that Pinus halepensis and Quercus ilex seedlings are probably limited by nutrient availability, particularly $\mathrm{P}$ and $\mathrm{K}$ in these Mediterranean degraded forest soils. However, nutrient status does not explain differences in seedling performance in the field within the range of conditions tested in this study. Fertilization experiments are needed to ascertain if increased nutrient availability beyond the levels found under natural conditions can promote seedling establishment and growth in these degraded soils.
Acknowledgments: This research has been carried out in the context of the REDMED project (ENV-CT97-0682), funded by the European Commission, the local Government of the Region of Valencia (Conselleria de Territorio y Vivienda, Generalitat Valenciana), and Fundación Bancaja.

\section{REFERENCES}

[1] Aerts R., Nutrient resorption from senescing leaves of perennials: are there general patterns? J. Ecol. 84 (1996) 597-608.

[2] Alifragis D., Smiris P., Maris F., Kavvadias V., Konstantinidou E., Stamou N., The effect of stand age on the accumulation of nutrients in the aboveground components of an Aleppo pine ecosystem, For. Ecol. Manage. 141 (2001) 259-269.

[3] Alonso C., Herrera C.M., Patterns made of patterns: variation and covariation of leaf nutrient concentrations within and between populations of Prunus mahaleb, New Phytol. 150 (2001) 629-640.

[4] Bazzaz F.A., Plants in Changing Environments - Linking Physiological, Population and Community Ecology, Cambridge University Press, Cambridge, 1996.

[5] Binkley D., Forest nutrition managament, Wiley, New York, 1986.

[6] Boardman R., Cromer R.N., Lambert M.J., Webb M.J., Forest plantations, in: Reuter D.J., Robinson J.B. (Eds.), Plant analysis - an interpretation manual, CSIRO Publ., Collingwood, 1997, pp. 505566.

[7] Bocio I., Navarro F.B., Ripoll M.A., Jiménez M.N., De Simón E., Holm oak (Quercus rotundifolia Lam.) and Aleppo pine (Pinus halepensis Mill.) response to different soil preparation techniques applied to forestation in abandoned farmland, Ann. For. Sci. 61 (2004) 171-178.

[8] Bonneau M., Le diagnostic foliaire, Rev. For. Fr. XL (1988) 19-28.

[9] Bottner P., Coûteaux M.M., Vallejo V.R., Soil organic matter in Mediterranean-type ecosystems and global climatic change: a case study - the soils of the Mediterranean basin, in: Moreno J.M., Oechel W.C. (Eds.), Global Change and Mediterranean-Type Ecosystems, Springer, New York, 1995, pp. 306-325.

[10] Burdett A.N., Physiological processes in plantation establishment and the development of specifications for forest planting stock, Can. J. For. Res. 20 (1990) 415-427.

[11] Canadell J., Vilà M., Variation in tissue element concentrations in Quercus ilex L. over a range of different soils, Vegetatio 99-100 (1992) 273-282.

[12] Canham C.D., Berkowitz A.R., Kelly V.R., Lovett G.M., Ollinger S.V., Schnurr J., Biomass allocation and multiple resource limitation in tree seedlings, Can. J. For. Res. 26 (1996) 1521-1530.

[13] Cornelissen J.H.C., Werger M.J.A., Castro-Diez P., van Rheenen J.W.A., Rowland A.P., Foliar nutrients in relation to growth, allocation and leaf traits in seedlings of a wide range of woody plant species and types, Oecologia 111 (1997) 460-469.

[14] Cuevas E., Medina E., Nutrient dynamics within amazonian forests: II. Fine root growth, nutrient availability and leaf litter decomposition, Oecologia 76 (1988) 222-235.

[15] Díaz E., Roldán A., Effects of reafforestation techniques on the nutrient content, photosynthetic rate and stomatal conductance of Pinus halepensis seedlings under semiarid conditions, Land Degrad. Dev. 11 (2000) 475-486.

[16] Espelta J.M., Riba M., Retana J., Patterns of seedling recruitment in West-Mediterranean Quercus ilex forests influenced by canopy development, J. Veg. Sci. 6 (1995) 465-472.

[17] FAO, Soil map of the world. Revised legend, Rome, 1988. 
[18] Fitter A.H., Strickland T., Architectural analysis of plant root systems: 2. Influence of nutrient supply on architecture in contrasting plant species, New Phytol. 118 (1991) 383-389.

[19] Gakis S., Mantzanas K., Alifragis D., Papanastasis V.P., Papaioannou A., Seilopoulos D., Platis P., Effects of understorey vegetation on tree establishment and growth in a silvopastoral system in northern Greece, Agroforest. Syst. 60 (2004) 149-157.

[20] Glyphis J.P., Puttick G.M., Phenolics, nutrition and insect herbivory in some garrigue and maquis plant species, Oecologia 78 (1989) 259-263.

[21] Grime J.P., Plant strategies and vegetation processes, Wiley, New York, 1979.

[22] Henkin Z., Noy-Meir I., Kafkafi U., Gutman M., Seligman N.G., Phosphate fertilization primes production of rangeland on brown rendzina soils in the Galilee, Israel, Agr. Ecosyst. Environ. 59 (1996) 43-53.

[23] Henkin Z., Seligman N.G., Noy-Meir I., Kafkafi U., Secondary succession after fire in a Mediterranean dwarf-shrub community, J. Veg. Sci. 10 (1999) 503-514.

[24] Ingestad T., Agren G.I., The influence of plant nutrition on biomass allocation, Ecol. Appl. 1 (1991) 168-174.

[25] Jackson R.B., Manwaring J.H., Caldwell M.M., Rapid physiological adjustment of roots to localized soil enrichment, Nature 344 (1990) 58-60.

[26] Koerselman W., Meuleman A.F.M., The vegetation N:P ratio: a new tool to detect the nature of nutrient limitation, J. Appl. Ecol. 33 (1996) 1441-1450.

[27] López Bermúdez F., Albaladejo J., Evironmental factors of soil degradation in the Mediterranean area, in: Albaladejo J., Stocking M.A., Díaz E. (Eds.), Soil degradation and rehabilitation in Mediterranean environmental conditions, CSIC, Murcia, 1990, pp. 15-45.

[28] Mamolos A.P., Elisseou G.K., Veresoglou D.S., Depth of root activity of coexisting grassland species in relation to $\mathrm{N}$ and $\mathrm{P}$ additions, measured using nonradioactive tracers, J. Ecol. 83 (1995) 643-652.

[29] Martínez Mena M., Alvarez Rogel J., Castillo V., Albaladejo J., Organic carbon and nitrogen losses influenced by vegetation removal in a semiarid mediterranean soil, Biogeochemistry 61 (2002) 309-321.

[30] Page A.L., Miller R.H., Keeney D.R. (Eds.), Methods of soil analysis. Part 2. Chemical and microbiological properties, ASA-SSSA, Madison, 1982.

[31] Orgeas J., Ourcival J.M., Bonin G., Seasonal and spatial patterns of foliar nutrients in cork oak (Quercus suber L.) growing on siliceous soils in Provence (France), Plant Ecol. 164 (2002) 201-211.

[32] Pausas J.G., Bladé C., Valdecantos A., Seva J.P., Fuentes D., Alloza J.A., Vilagrosa A., Bautista S., Cortina J., Vallejo R., Pines and oaks in the restoration of Mediterranean landscapes of Spain: New perspectives for an old practice - a review, Plant Ecol. 171 (2004) 209-220.

[33] Raaimakers D., Lambers H., Response to phosphorus supply of tropical tree seedlings:a comparison between a pioneer species Tapirira obtusa and a climax species Lecythis corrugata, New Phytol. 132 (1996) 97-102.
[34] Raich J.W., Riley R.H., Vitousek P.M., Use of ingrowth cores to assess nutrient limitation in forest ecosystems, Can. J. For. Res. 24 (1994) 2135-2138.

[35] Robles C., Ballini C., Garzino S., Bonin G., Functional reactions of mediterranean sclerophyllous ecosystems to clearing impact, Ann. For. Sci. 57 (2000) 267-276.

[36] Rodà F., Mayor X., Sabaté S., Diego V., Water and nutrient limitations to primary production, in: Rodà F., Retana J., Gracia C.A., Bellot J. (Eds.), Ecology of Mediterranean evergreen oak forests, Springer-Verlag, Berlin, 1999, pp. 183-194.

[37] Romanyà J., Vallejo V.R., Productivity of Pinus radiata plantations in Spain in response to climate and soil, For. Ecol. Manage. 195 (2004) 177-189.

[38] Sabaté S., Gracia C.A., Canopy nutrient content of a Quercus ilex L. forest: fertilization and irrigation effects, For. Ecol. Manage. 68 (1994) 31-37.

[39] Sabaté S., Sala A., Gracia C.A., Nutrient content in Quercus ilex canopies: Seasonal and spatial variation within a catchment, Plant Soil 168-169 (1995) 297-304.

[40] Sardans J., Rodà F., Peñuelas J., Phosphorus limitation and competitive capacities of Pinus halepensis and Quercus ilex subsp. rotundifolia on different soils, Plant Ecol. 174 (2004) 307-319.

[41] Specht R.L., Rundel P.W., Sclerophylly and foliar nutrient status of Mediterranean-climate plant communities in southern Australia, Aust. J. Bot. 38 (1990) 459-474.

[42] Tapias R., Climent J., Pardos J.A., Gil L., Life histories of Mediterranean pines, Plant Ecol. 171 (2004) 53-68.

[43] Tyler G., Mineral nutrient limitations of calcifuge plants in phosphate sufficient limestone soil, Ann. Bot. 77 (1996) 649-656.

[44] Valdecantos A., Aplicación de fertilizantes orgánicos e inorgánicos en la repoblación de zonas forestales degradadas de la Comunidad Valenciana, [on line] Biblioteca Virtual Miguel de Cervantes, Alicante, Ph.D. thesis, 2003, http://www.cervantesvirtual.com/Ficha Obra.html?Ref=10767.

[45] Van den Driessche R., Prediction of mineral nutrient status of trees by foliar analysis, The Botanical Review 40 (1974) 347-394.

[46] Vilagrosa A., Seva J.P., Valdecantos A., Cortina J., Alloza J.A., Serrasolses I., Diego V., Abril M., Ferran A., Bellot J.,Vallejo V.R., Plantaciones para la restauración forestal en la Comunidad Valenciana, in: Vallejo V.R. (Ed.), La restauración de la cubierta vegetal en la Comunidad Valenciana, CEAM, Valencia, 1997, pp. 435-546.

[47] Watanabe F.S., Olsen S.R., Test of an ascorbic acid method for determining phosphorus in water and $\mathrm{NaHCO}_{3}$ extracts from soils, Soil Soc. Am. Sci. Proc. 29 (1965) 677-678.

[48] Weetman G.F., Graphic vector analysis technique for testing stand nutritional status, in: Dyck W.J., Mees C.A. (Eds.), Research strategies for long-term site productivity, Ministry of Forestry of New Zealand, 1989, pp. 93-109.

[49] Wilson S.D., Plant interactions during secondary succession, in: Walker L.R. (Ed.)., Ecosystems of disturbed ground, Elsevier, Amsterdam, 1999, pp. 629-650. 